ARTICLES / ARTIGOS

DOI: $10.5433 / 1679-0367.2021 v 42 n 1 p 29$

\title{
Occurrence of Escherichia coli in salmon sashimis commercialized in restaurants from Londrina - PR
}

\section{Ocorrência de Escherichia coli em sashimis de salmão comercializados em restaurantes de Londrina - PR}

\author{
Mayara Fernanda de Carvalho Proença ${ }^{1}$, Thaís Cardoso Nascimento ${ }^{1}$, \\ Daniele Zendrini Rechenchoski², Angélica Marim Lopes ${ }^{3}$
}

\begin{abstract}
The population interest for fish consumption has increased, mainly due to several beneficial nutritional properties presented by this food. In this context, oriental culinary also brings different eating habits as consume raw food, such as sashimi. A relevant food contaminant of fecal origin is Escherichia coli, able to become potentially harmful, when it acquires virulence factors, as Shiga toxin-producing $E$. coli (STEC). This study aimed to evaluate 30 samples of salmon sashimi regarding the presence of E. coli, as well as perform the genotypic characterization of virulence factors associated with STEC. Three samples were collected from 10 different restaurants, specialized in Japanese culinary in the city of Londrina - PR. The E. coli identification was performed using the Colilert ${ }^{\circledR}$ chromogenic $^{2}$ substrate technique and biochemical tests, and for the investigation of virulence genes, stxl and stx2, the polymerase chain reaction (PCR) was used. Among the 30 samples analyzed, $15(50 \%)$ presented contamination by $E$. coli. However, in no sample were detected virulence factors associated with STEC. Although human diseases associated with STEC are poorly described in Brazil, it is possible to verify that fish, mainly those consumed raw, are potential transmitters of $E$. coli to humans. This can compromise the food safety of these products and, thus, characterize them as unsuitable for consumption. Therefore, it is necessary the adoption of preventive measures of contamination by $E$. coli in products intended to human consumption, beyond more research that can verify the potential of STEC as a fish contaminant.
\end{abstract}

Keywords: E. coli. Salmon. Japanese culinary. Microbial contamination. Food safety.

\footnotetext{
${ }^{1}$ Majored in Pharmacy from Faculdade Dom Bosco, Cornélio Procópio, Paraná, Brazil.

${ }^{2} \mathrm{PhD}$ in Microbiology from Universidade Estadual de Londrina (UEL), Londrina, Paraná, Brazil. Professor in Faculdade Dom Bosco, Cornélio Procópio, Paraná, Brazil.

${ }^{3} \mathrm{PhD}$ in Microbiology from Universidade Estadual de Londrina, Londrina, Paraná, Brazil. Professor in Faculdade Dom Bosco, Cornélio Procópio, Paraná, Brazil. E-mail: angelopes_8@hotmail.com
} 


\section{Resumo}

O interesse da população pelo consumo de peixe tem aumentado, principalmente devido às diversas propriedades nutricionais benéficas apresentadas por este alimento. Neste contexto, a culinária oriental também traz diferentes hábitos alimentares, como consumir alimentos crus, tais como o sashimi. Um relevante contaminante alimentar de origem fecal é Escherichia coli, capaz de tornarse potencialmente danosa ao adquirir fatores de virulência, como E. coli produtora de toxina Shiga (STEC). Este estudo objetivou avaliar 30 amostras de sashimi de salmão quanto à presença de $E$. coli, bem como realizar a caracterização genotípica de fatores de virulência associados com STEC. Três amostras foram coletadas de 10 diferentes restaurantes especializados em culinária japonesa da cidade de Londrina - PR. A identificação de E. coli foi realizada utilizando a técnica de substrato cromogênico Colilert ${ }^{\circledR}$ e testes bioquímicos, e para a investigação dos genes de virulência, stx 1 e stx2, a reação em cadeia da polimerase (PCR) foi utilizada. Dentre as 30 amostras analisadas, 15 (50\%) apresentaram contaminação por E. coli. Contudo, em nenhuma das amostras foram detectados fatores de virulência associados com STEC. Embora as doenças humanas associadas com STEC sejam pouco descritas no Brasil, é possível verificar que os peixes, principalmente aqueles consumidos crus, são potenciais transmissores de $E$. coli aos humanos. Isto pode comprometer a segurança alimentar destes produtos e, assim, caracterizá-los como impróprios para o consumo. Portanto, é necessária a adoção de medidas preventivas de contaminação por $E$. coli nos produtos destinados ao consumo humano, além de mais pesquisas que possam verificar o potencial de STEC como um contaminante de peixes.

Palavras-chave: E. coli. Salmão. Culinária japonesa. Contaminação microbiana. Segurança alimentar.

\section{Introduction}

The population interest for fish consumption has increased due to the association of its ingestion with improvement in health. This food presents several beneficial nutritional properties, as the high biological value of proteins, high levels of micronutrients, low levels of saturated fat and high level of polyunsaturated fatty acids, as omega-3. (1-3) $^{-3}$

Among the fish, salmon in natura in the form of sushi or sashimi is widely consumed in Brazil due the popularization of Japanese culinary. The salmon is rich in liposoluble vitamins (A and D) and minerals such as calcium, copper, iron, phosphorus, magnesium, manganese, selenium and zinc. ${ }^{(1,3)}$

However, as sashimi is consumed raw, not receiving heat treatment able to eliminate or minimize pathogenic microorganisms, it is considered a food with potential risk to consumer health. ${ }^{(4)}$ Thus, the consumption of sashimi becomes a concern for public health, not only because it is considered a highly perishable food, but also due to the hygienic-sanitary conditions in which it is prepared and preserved. ${ }^{(5)}$
The number of foodborne diseases is increasing significantly and among their etiological agents, bacteria are the most important group. ${ }^{(6)}$ The Shiga toxin-producing Escherichia coli (STEC) strain has its pathogenicity related to the ability to adhering the intestinal mucosa and produce toxins. The food contamination by STEC can cause complications, such as, the hemolytic uremic syndrome and hemorrhagic colitis. ${ }^{(7)}$ The increased raw fish consumption and the hygienicsanitary conditions involved throughout the production process are directly associated to contamination and the possibility of infection by E. coli strains, presenting virulence factors of STEC pathotype.

Although diarrheal diseases in humans associated with STEC have not been frequently reported in Brazil, national studies in cattle evidence the prevalence of this strain in the country, as well as correlation between serotypes found in these animals and in human patients. ${ }^{(8)}$ The occurrence of STEC in Brazil was investigated, being that its positivity varied from 1.4 to $71 \%$ in cattle, from 0 to $18.1 \%$ in food sources of animal origin and water and from 0.6 to $6.3 \%$ in human clinical 
samples. Significant differences in the isolation rates and serotypes were observed. ${ }^{(9)}$ In addition, Brazil borders Argentina, where $80 \%$ of the meat consumed is not properly controlled or inspected, justifying the high incidence of STEC infections. ${ }^{(10)}$ In Brazil, the information available on the subject is still scarce, although are recognized sporadic cases of diarrhea by STEC, which occur more frequently in children. ${ }^{(11)}$ Studies performed in the states of São Paulo and Paraná using feces from children with diarrhea report a frequency of STEC of approximately $1 \%$, however there are no reports of outbreaks associated involving STEC in the country. ${ }^{(12-13)}$

There are some documents that have compiled global STEC data based on sites of health institutions and overview by continent. However, the prevalence and distribution of STEC in Brazil remains unclear. This study aimed to evaluate 30 samples of salmon sashimi sold in specialized restaurants of Japanese culinary in the city of Londrina, north of Paraná, south of Brazil, regarding the presence of E. coli, as well as perform the genotypic characterization of virulence factors associated with STEC.

\section{Material and Methods}

Sampling and prepare of the samples

Thirty samples of salmon fish sashimi were collected, being three samples from 10 different restaurants, identified as follows: R1-R10, all ten establishments specialized in Japanese culinary in the city of Londrina - PR, during the period of December 2016. After the purchase through of self-service or table service, the samples collected of balcony or table were packed in sterile bags in isothermal boxes with ice and transported to the laboratory for analysis within $6 \mathrm{~h}$.

Aseptically, $25 \mathrm{~g}$ of each sample were weighed in a semi-analytical balance and later diluted in $225 \mathrm{~mL}$ of $1 \%$ peptone water and homogenized for $20 \mathrm{~min}$.
Isolation and identification of E. coli

E. coli identification was performed using the Colilert ${ }^{\circledR}$ (Sovereign - USA) chromogenic substrate technique, which can also be applied to different food matrices as suggested by Oliveira. ${ }^{(14)}$ According to this technique, as described by Schuroff et al., ${ }^{(15)} 100 \mathrm{~mL}$ of each sample was poured into a sterile bottle and transferred to the Quanti-Tray (WP2000) and the Colilert ${ }^{\circledR}$ reagent added. After homogenization, it was used the sealer Quanti-Tray Sealer (IDEXX/Sovereign USA). Then, Quanti-Trays were incubated at $37^{\circ} \mathrm{C}$ $\pm 2{ }^{\circ} \mathrm{C}$ for $24 \mathrm{~h}$ and examined under UV light at $365 \mathrm{~nm}$. The yellow wells that become fluorescent blue indicated the presence of E. coli.

Aliquots of the fluorescent wells were collected with sterile syringe and transferred to the Broth E. coli at $35^{\circ} \mathrm{C}$ for $24 \mathrm{~h}$. After this period, the samples were streaked onto MacConkey Agar and incubated under the same conditions. Presumptive E. coli colonies were selected and submitted to biochemical screening using the EPM, MILi and Simmons Citrate $\left(\right.$ Difco $\left.^{\mathrm{TM}}\right)$. Biochemically identified $E$. coli isolates were stored in stock agar at room temperature and at $-20{ }^{\circ} \mathrm{C}$ in Brain Heart Infusion (BHI) broth with $20 \%$ (v/v) glycerol.

For the search of serotype O157:H7, the samples were streaked onto sorbitol MacConkey Agar and those with typical characteristics were submitted to biochemical identification.

\section{Search for virulence genes}

All isolates were screened for the presence of virulence genes, stx 1 and stx2, using PCR, as described by Paton and Paton (Table 1). ${ }^{(16)}$ Initially, to extraction of bacterial DNA, E. coli isolates were grown in Luria-Bertani Agar at $37^{\circ} \mathrm{C}$ for $24 \mathrm{~h}$. The cultures were suspended in $300 \mu \mathrm{L}$ of sterile ultrapure water. The bacteria were lysed by boiling for $10 \mathrm{~min}$ in a water bath $\left(100^{\circ} \mathrm{C}\right) .{ }^{(17)}$ Posteriorly, they were cooled in ice for $5 \mathrm{~min}$ and centrifuged at $1000 \mathrm{rpm}$ for the same period. 
The PCR was performed in a Biocycler $^{\circledR}$ thermocycler, in $25 \mu \mathrm{L}$ reaction volume, containing $2 \mu \mathrm{L}$ of DNA sample, $200 \mu \mathrm{M}$ of dNTP's, $1.5 \mathrm{mM}$ of $\mathrm{MgCl}_{2}, 20 \mathrm{pmol}$ of each primer and $1.5 \mathrm{U}$ of Taq DNA polymerase (Invitrogen ${ }^{\mathrm{TM}}$ ). PCR amplifica- tion products were subjected to electrophoresis on a $1.5 \%$ agarose gel, stained with $\mathrm{SYBR}^{\circledR}$ Safe and visualized under UV light. EDL933 (E. coli O157:H7) and HB101 (E. coli K-12) were used as positive and negative controls, respectively. ${ }^{(15)}$

Table 1 - Primers used for PCR in the present study.

\begin{tabular}{ccccc}
\hline \multirow{2}{*}{ Gene } & Primer Sequence $\left(\mathbf{5}^{\prime} \rightarrow \mathbf{3}^{\prime}\right)$ & $\begin{array}{c}\text { Amplicon size } \\
(\mathbf{p b})\end{array}$ & $\begin{array}{c}\text { Annealing temp. } \\
\left({ }^{\circ} \mathbf{C}\right)\end{array}$ & Reference \\
\hline \multirow{2}{*}{ stx 1} & $\begin{array}{c}\text { (F) ATAAATCGCCATTCGTTGACTAC } \\
\text { (R) AGAACGCCCACTGAGATCATC }\end{array}$ & 180 & $60{ }^{\circ} \mathrm{C}$ & $\begin{array}{c}\text { Paton; Paton, } \\
1998^{(16)}\end{array}$ \\
\multirow{2}{*}{ stx 2} & $\begin{array}{l}\text { (F) GGCACTGTCTGAAACTGCTCC } \\
\text { (R) TCGCCAGTTATCTGACATTCTG }\end{array}$ & 255 & $60{ }^{\circ} \mathrm{C}$ & $\begin{array}{c}\text { Paton; Paton, } \\
1998^{(16)}\end{array}$ \\
\hline
\end{tabular}

Source: Authors

\section{Results and Discussion}

In this study, the biochemical tests confirmed $100 \%$ of the bacteria presumptively identified as E. coli by Colilert $^{\circledR}$, however strains of E. coli
O157:H7 were not found. Among the 30 samples analyzed, $15(50 \%)$ presented contamination by $E$. coli (Table 2), highlighting the potential of fishes in the transmission of this microorganism to humans.

Table 2 - Search results for the identification of E. coli in sashimi samples.

\begin{tabular}{cc}
\hline Restaurants & E. coli* \\
\hline R1 & Absent \\
R2 & Absent \\
R3 & Present \\
R4 & Absent \\
R5 & Present \\
R6 & Absent \\
R7 & Present \\
R8 & Present \\
R9 & Absent \\
R10 & Present
\end{tabular}

*Result of three concordant samples analyzed from each restaurant.

Source: Authors

Similarly, Freire et al. ${ }^{(18)}$ collected salmon fish sashimis on specialized and non-specialized establishments in oriental culinary, commercialized in the city of Mossoró, state of Rio Grande do Norte, Brazil, where from 12 analyzed samples, six were contaminated by E. coli. 
Moura Filho et al. ${ }^{(19)}$ evaluated the microbiological quality of sashimis and vegetables that accompanied them in the restaurants of Recife, Pernambuco, Brazil. They detected E. coli in 10 of the 30 samples analyzed, being 2 sashimis and 8 vegetables. According to Cardozo et al., ${ }^{(20)}$ E. coli does not belong to fish gut microbiota. Then, when it is found in these animals, it can be relatively linked to the contaminated water where these fish live, becoming a source of transmission of this pathogen.

Barbosa et al. ${ }^{(21)}$ identified 115 E. coli isolates, 19 were obtained from water, and 96 were obtained from fish. Regarding fish isolates, 26 were recovered from the skin, 65 from the gastrointestinal tract and five from the muscle. Based on the analysis, water, skin and the gastrointestinal tract presented a higher correspondence and a higher number of isolates; thus, they are possible means for the transmission of $E$. coli serotypes that cause diarrhea. In addition, the water used for ice production is also considered critical factor. Ferreira et al. ${ }^{(22)}$ analyzed eight ice samples used in fish conservation and found that six (75\%) were contaminated by total and thermotolerant coliforms, and two (25\%) by E. coli, indicating poor hygienic-sanitary quality of this product.

The quality of fresh fish may also be influenced by manipulators non-hygienic habits. The sashimi is a food that is in constant manipulation and does not receive previous heat treatment able to eliminate or at least minimize the risk of possible contaminant microorganisms. ${ }^{(23)}$

Prado et al. ${ }^{(24)}$ analyzed a sushibar observing inadequate hygienic procedures, such as the noncontrol of the binomial time and temperature, inadequate cleaning of hands, fruits and vegetables, utensils and equipment, besides the lack of sushiman training, being that the training and supervision of these professionals are important preventive measures.

Another relevant factor is the health of food handlers, that is, everyone who can come into contact with the product, at any food chain stage, play an important role in preparations quality, being the health and hygiene of these professionals directly related to food safety. ${ }^{(25)}$

E. coli is an important food contaminant and when acquires specific virulence factors, it becomes potentially harmful, as is the case of STEC. ${ }^{(26)}$ Carvalho et al. ${ }^{(27)}$ highlighted among the STEC transmission forms the ingestion of raw or undercooked meat, being the sashimi important contamination source. Despite its importance as a food contaminant, in the present study, the STEC virulence factors investigated were not detected in any of the E. coli isolates (Table 3).

Table 3 - Result of genotypic characterization of virulence factors associated with STEC.

\begin{tabular}{cll}
\hline Restaurants & stx $\mathbf{1}^{*}$ & $\boldsymbol{s t} \mathbf{x} \mathbf{2}^{*}$ \\
\hline R3 & Negative & Negative \\
R5 & Negative & Negative \\
R7 & Negative & Negative \\
R8 & Negative & Negative \\
R10 & Negative & Negative \\
\hline
\end{tabular}

*Result of three concordant samples analyzed from each restaurant.

Source: Authors

However, Cardozo et al. ${ }^{(20)}$ investigated the presence of pathotypes STEC and EPEC (enteropathogenic E. coli) in farmed fish and free- living fish. From 373 analyzed samples from the fish farm, one $(0.2 \%)$ tested positive for a STEC related gene and of the 99 free-living fish analyzed 
samples, six $(6 \%)$ were positive for at least one of the STEC or EPEC related genes, demonstrating how these fishes contribute to humans infections. Kumar et al. ${ }^{(28)}$ analyzed fresh seafood and meat marketed in the city of Mangalore, Karnataka, India and genes of STEC were found in two of the 60 fish samples and two of the 48 clam samples.

Finally, although the investigation here reported does not represent a sufficient number of samples to make the results conclusive, studies reporting salmon contamination by STEC are scarce. Recently, in the study of Ramires et al. ${ }^{(29)}$ was evaluated the microbiological quality of salmon sushi samples, in the city of Pelotas - RS, Brazil. Interestingly, of the 28 samples examined, just one was found to be positive for E. coli; however, this isolate was characterized as $E$. coli $\mathrm{O} 157: \mathrm{H} 7$. This isolate presented virulence genes stx 1 , stx2, eae and $h l y A$ and had the ability to form biofilms on stainless steel, suggesting the possibility of persistent contamination throughout the production process, since this is the material most used in food-processing and storage environments.

\section{Conclusion}

Sashimis prepared in establishments specialized in Japanese culinary can present risks to consumer health, since they can be contaminated by $E$. coli. This microorganism may indicate inappropriate contamination of raw material or contamination during food preparation as well as inadequate sanitation or cleaning practices. Pursuant to these results and the increase in the consumption of raw salmon, there is a need to improve the good hygiene practices adopted in establishments selling sashimi to minimize the risk of contamination by deteriorating or pathogenic bacteria that may cause harm to the health of consumers.

Regarding the research of STEC virulence factors, a wider study of the topic is essential, since most studies reported STEC contamination in foods of bovine origin, thus hampering a conclusive investigation of the contamination of fish in relation to STEC.

\section{References}

1 Franco MLRS, Uchimura CM, Prado $M$, Yajima EM, Gasparino E, Silva SCC. Qualidade da pele do salmão, Salmo solaris: teste de resistência e hidroxiprolina. Arq Ciên Mar. 2013;46(1):90-5. doi: doi.org/10.32360/ acmar.v46i1.894.

2 Santiago JDAS, Araújo PFR, Santiago AP, Carvalho FCT, Vieira RHSF. Bactérias patogênicas relacionadas à ingestão de pescadosrevisão. Arq Ciên Mar. 2013;46(2):92-103. doi: 10.32360/acmar.v46i2.908.

3 Sartori AGO, Amancio RD. Pescado: importância nutricional e consumo no Brasil. Segur Aliment Nutr. 2012;19(2):83-93. doi: 10.20396/ san.v19i2.8634613.

4 Braghini F, Alexandrino EG, Leite FP, Kemmelmeier EG, Gonçalves JE. Análise microbiológica de sashimis à base de salmão, comercializados na cidade de Maringá-PR. Enciclopédia Biosfera. 2015;11(22):3165-75. doi: 10.18677/Enciclopedia_Biosfera_2015 034.

5 Guimarães KP, Silva RMR, Guimarães KP. Investigação da qualidade microbiológica de sushis comercializados nas cidades de Crato e Juazeiro do Norte-CE. Rev E-Ciênc. 2017; 4(2):20-5. doi: 10.19095/rec.v4i2.166.

6 Melo ES, Amorim WR, Pinheiro REE, Corrêa PGN, Carvalho SMR, Santos ARSS, et al. Doenças transmitidas por alimentos e principais agentes bacterianos envolvidos em surtos no Brasil. Pubvet. 2018;12(10):1-9. doi: 10.31533/ pubvet.v12n10a191.1-9.

7 Tanquilut CD, Jung CW, Nelson AW, Lau SK. Infection due to Shiga toxin-producing enterohemorrhagic Escherichia coli (EHEC) presenting as ischemic colitis. IDCases. 2019;18:e00629. doi: 10.1016/j.idcr.2019. e00629.

8 Bertão AMS, Saridakis HO. Escherichia coli produtora de toxina shiga (STEC): principais fatores de virulência e dados epidemiológicos. Semina Cienc Biol Saude. 2007;28(2):81-92. doi: 10.5433/1679-0367.2007v28n2p81. 
9 Caldorin M, Almeida IAZCD, Peresi JTM, Alves EC. Ocorrência de Escherichia coli produtora de toxina Shiga (STEC) no Brasil e sua importância em saúde pública. Bol Epidemiol Paul. 2013;10(110):4-20.

10 Lopez EL, Contrini MM, Rosa MF. Epidemiology of Shiga toxin producing Escherichia coli infections in South America. In: Kaper JB, O'Brien AD, editors. Escherichia coli $\mathrm{O} 157: \mathrm{H} 7$ and other Shiga toxin-producing E. coli strains. Washington: ASM Press; 1998. p. 30-37.

11 Paton JC, Paton AW. Patogenesis and diagnosis of Shiga toxin-producing Escherichia coli infections. Clin Microbiol Rev. 1998;11(3):45079. doi: 10.1128/CMR.11.3.450.

12 Guth BEC, Ramos SRTS, Cerqueira AMF, Andrade JRC, Gomes TAT. Phenotypic and genotypic characteristics of Shiga toxinproducing Escherichia coli strains isolated from children in São Paulo, Brazil. Mem Inst Oswaldo Cruz. 2002;97(8):1085-9. doi: 10.1590/S0074-02762002000800003.

13 Toni F, Souza EM, Klassen G, Rigo LU, Steffens MBR, Cruz CR, et al. Detecção de Escherichia coli Shiga toxigênica (STEC) através da amplificação dos genes stx. Rev Bras Anal Clin. 2004;36(2):73-7. Id: lil-490785.

14 Oliveira CFPMD. Aplicação do Colilert $^{\circledR}$ à enumeração de Escherichia coli em alimentos [dissertation]. Peniche, Leiria (PRT): Escola Superior de Turismo e Tecnologia do Mar e Instituto Politécnico de Leiria; 2013.

15 Schuroff PA, Lima NR, Burgos TN, Lopes AM, Pelayo JS. Qualidade microbiológica da água do Lago Igapó de Londrina-PR e caracterização genotípica de fatores de virulência associados à Escherichia coli enteropatogênica (EPEC) e E. coli produtora de toxina Shiga (STEC). Semina Cien Biol Saude. 2014;35(2):11-20. doi: 10.5433/1679-0367.2014v35n2p11.

16 Paton AW, Paton JC. Detection and characterization of Shiga toxigenic Escherichia coli by using multiplex PCR assays for $s t x_{1}, s t x_{2}$, eaeA, enterohemorrhagic E. coli hlyA, $r f b_{0111}$, and $r f b_{0157 .}$ J Clin Microbiol. 1998;36(2):598602. PMID: 9466788.
17 Lascowski KMS, Guth BEC, Martins FH, Rocha SPD, Irino K, Pelayo JS. Shiga toxinproducing Escherichia coli in drinking water supplies of north Paraná State, Brazil. J Appl Microbiol. 2013;114(4):1230-9. doi: 10.1111/ jam.12113.

18 Freire BCF, Soares KMP, Filho PTPS, Melo ECC, Souza LB. Micro-organismos indicadores do grupo coliformes em sashimis de salmão comercializados na cidade de Mossoró, Rio Grande do Norte. Rev Verde Agroecologia Desenvolv Sustent. 2017;12(4):810-3. doi: 10.18378/rvads.v12i4.4835.

19 Moura Filho LGM, Mendes ES, Pinheiro RP, Góes LMNB, Vieira KPBA, Mendes PP. Enumeração e pesquisa de Vibrio spp. e coliformes totais e termotolerantes em sashimis de atum e vegetais comercializados na região metropolitana do Recife, Estado de Pernambuco. Acta Sci Technol. 2007;29(1):8590. doi: 10.4025/actascitechnol.v29i1.94.

20 Cardozo MV, Borges CA, Beraldo LG, Maluta RP, Pollo AS, Borzi MM, et al. Shigatoxigenic and atypical enteropathogenic Escherichia coli in fish for human consumption. Braz $\mathrm{J}$ Microbiol. 2018;49(4):936-41. doi: 10.1016/j. bjm.2018.02.013.

21 Barbosa MMC, Pinto FDR, Ribeiro LF, Guriz CSL, Ferraudo AS, Maluta RP, et al. Serology and patterns of antimicrobial susceptibility in Escherichia coli isolates from pay-to-fish ponds. Arq Inst Biol. 2014;81(1):43-8. doi: 10.1590/S1808-16572014000100008.

22 Ferreira EM, Lopes IDS, Pereira DDM, Rodrigues LDC, Costa FN. Qualidade microbiológica do peixe-serra (Scomberomerus brasiliensis) e do gelo utilizado na sua conservação. Arq Inst Biol. 2014;81(1):49-54. doi: $10.1590 /$ S1808-16572014000100009.

23 Mouta RMA, Melo MB, Araújo AB, Aguiar FLL, Fontenelle ROS. Qualidade microbiológica do sushi comercializado na cidade de Sobral-CE. Rev Univ Vale Rio Verde. 2014;12(2):277-84. doi: 10.5892/ruvrd. v12i2.1447. 
24 Prado BG, Iwatani JE, Pereira MR, Gollucke APB, Toledo LP. Pontos críticos de controle na qualidade higiênico-sanitária do preparo de sushis e sashimis no município de São Vicente, São Paulo. Segur Aliment Nutr. 2014; 21(1):359-72. doi: 10.20396/san.v21i1.1661.

25 Medeiros MDGGD, Carvalho LRD, Franco RM. Percepção sobre a higiene dos manipuladores de alimentos e perfil microbiológico em restaurante universitário. Ciên Saúde Colet. 2017;22(2):383-92. doi: 10.1590/141381232017222.17282015 .

26 Pizarro MA, Orozco JH, Degarbo SM, Calderón AE, Nardello AL, Laciar A, et al. Virulence profiles of Shiga toxin-producing Escherichia coli and other potentially diarrheagenic $E$. coli of bovine origin, in Mendoza, Argentina. Braz J Microbiol. 2013;44(4):1173-80. doi: 10.1590/S1517-83822014005000010.

27 Carvalho AF, Miyashiro S, Nassar AF, Noda A, Gabriel DT, Baldassi L. Caracterização molecular e fenotípica de estirpes de Escherichia coli produtoras de shiga-toxina (STEC) não-O157 de fezes e carcaças bovinas. Arq Bras Med Vet Zootec. 2012;64(4):881-6. doi: 10.1590/S0102-09352012000400014.

28 Kumar HS, Otta SK, Karunasagar I, Karunasagar I. Detection of Shiga-toxigenic Escherichia coli (STEC) in fresh seafood and meat marketed in Mangalore, India by PCR. Lett Appl Microbiol. 2001;33(5):334-8. doi: 10.1046/j.1472-765x.2001.01007.x.

29 Ramires T, Iglesias MA, Vitola HS, Núncio ASP, Kroning IS, Kleinubing NR., et al. First report of Escherichia coli O157: $\mathrm{H} 7$ in ready to eat sushi. J Appl Microbiol. 2019;128(1):3019. doi: 10.1111/jam.14456. 